\title{
Literary Theory and Young Adult Literature: The Open Frontier in Critical Studies
}

E

ver since the enormous publication success of $\mathrm{J}$.

K. Rowling's Harry Potter series, contemporary

Young Adult (YA) literature has seen a rise in its appreciation by those who, in the past, might not have given YA literature a second glance. This is not to say, of course, that significant works categorized as YA have not been out there, only that contemporary works that have been labeled as YA tend to be ignored by many serious literary critics. Some still believe that YA literature is merely a secondary category of childlike storytelling - didactic in nature-and unworthy of serious literary evaluation, when, in fact, it is really an overlooked and underappreciated literary genre that has only recently begun to attract the critical attention that it deserves.

Many people have argued that YA literature, which is often grouped as a sub-division within the category of children's literature, isn't worth much attention because it doesn't offer enough substance to be included within the traditional literary canon. Deborah Stevenson, in her essay "Sentiment and Significance: The Impossibility of Recovery in the Children's Literature Canon or, The Drowning of The Water-Babies" goes so far as to argue that the "academic curriculum, which is based on a canon of significance, may rediscover the historical significance of a children's author but can never truly recover it to the literature's dominant popular canon" (112-113). She contends that there are too many other factors that disallow critics to view the literature as literature, even while she acknowledges that "children's literature scholarship is by no means invalid; it sheds much light on literature as a whole as well as the genre it discusses" (113). Unfortunately, many people working in literary theory and criticism are foregoing the opportunity to explore this phenomenon because they mistakenly believe that works labeled as YA should only be analyzed in terms of the connection-whether that be historical or psychological-to the supposed "intended" reader. They see the phrase YA, and they tend to dismiss the work as disconnected to the literary community.

The problem, of course, is exacerbated by the actual labeling of the genres: it should be readily apparent that YA literature is not the same thing as children's literature-in the same way that short fiction is not the same genre as the novel. Yet contemporary critics often speak of the two as if they were one and the same. What would help in this regard would be not only for critics to recognize the difference between the genres, but to simply acknowledge that regardless of genre, both children's and YA works are literature. ${ }^{1}$

In fact, the idea that YA works are truly literature is what lies at the heart of the "theory barrier" problem, even though in reality the problem is not of a literary nature. Terry Davis, in his article "On the Question of Integrating Young Adult Literature into the Mainstream," reminds us that:

Although a few books do cross over and become literature for both young people and adults-To Kill a Mockingbird and Ordinary People are two examples-most young adult books can't cross the boundary into grown-up literature for the following reasons: 1 . because publishers present most of the books in a package that an older teenager or adult wouldn't want to pick up and carry around, let alone read; and 2 . because many of us who write about these books 
and teach them and have charge of them on behalf of young readers refuse to hold the books to real literary standards. (5)

If we, as scholars and as readers, don't bother to hold the YA work up to the light of crucial literary standards, then it is no wonder the works are not being taken seriously. Critics, as the experts in literary analysis, need to take charge. This includes the idea of separating YA literature from children's literature-not to classify one as better than the other-but rather to acknowledge the differences in the literary craft itself, which in turn will lead to a greater understanding of the works themselves. For example, Stevenson's article mentions several texts that she includes in the body of children's literature, including Maurice Sendak's Where the Wild Things Are, Lewis Carroll's Alice in Wonderland, and Katherine Patterson's Bridge to Terabithia. What Stevenson fails to realize, though, is that Wild Things is of the children's literature genre; Alice is classic YA literature (just as The Scarlet Letter is classic literature); and Patterson's work is contemporary YA literature (just as Richard Ford's Independence Day is contemporary literature). If these works must be categorized, then the least we can do is categorize them appropriately. ${ }^{2}$

Davis takes this idea a step further when he suggests that "publishers need to create a specific category for books that can be read by adults and youth, books that have both literary and teaching merit" (5). The heart of this suggestion is what is truly important because while publishers may not be willing to start yet another marketing category, critics can, through individual analyses of works, reveal exactly which titles belong in this area, just as they do with other 'adult' contemporary works.

Of course, this is not a new idea. James Steel Smith in his 1967 text A Critical Approach to Children's Literature points out that of the "five ways of thinking about children's reading-historical, subject-centered, by types, psychological, and application-oriented, or utilitarian-all have one very important characteristic: None of them examines and analyzes the children's literature itself with any seriousness and care” (3). His text, even as early as 1967, called for a reconsideration of this problem. The difference today lies in the burgeoning attitude of respectability that YA literature is receiving in the present day, thanks in no small measure to the success of J. K. Rowling and her creation of Harry Potter, the quintessential main character of her series of novels. It seems that Harry Potter has opened up a whole new arena of respectable scholarly debate. ${ }^{3}$

One text centered on the Harry Potter phenomenon that proves the point that significant literary analysis can be undertaken successfully with YA literature is Giselle Liza Anatol's collection of essays titled Reading Harry Potter: Critical Essays. The critical analyses include titles such as Veronica L. Schanoes "Cruel Heroes and Treacherous Texts: Educating the Reader in Moral Complexity and Critical Reading in J. K. Rowling's Harry Potter Books.” Clearly, Harry Potter has inspired many a critic to jump on the YA literary bandwagon, so why not examine other contemporary YA texts in the same way? After all, it's not just J. K. Rowling's work that is worthy of study. "Serious writers don't condescend in terms of style or any other way. They try to perceive human life as deeply and clearly as they can every time they tell a story, and every time they tell a story they try to present their perceptions in the best-the most vivid-prose they can craft. That's why we call it art and that's why serious writers deserve to be called artists" (Davis 7). And there are many YA authors out there who are literary artists.

Furthermore, if, as David L. Russell states, "Literary criticism is the discussion of literature undertaken in order to interpret its meaning and to evaluate its quality" (48), and it is also true that "the purpose of criticism is to promote high standards in literature and to encourage a general appreciation of literature among readers" (48), then there is absolutely no reason to avoid the serious scholarly study of YA literature. These are works that have significance to all of us, regardless of which age category we fall into, because they speak to the human condition. After all, as Davis asserts, "If we're going to call it literature, whether or not we preface the word with the young adult qualifier, then ... we should hold it to the standards of literature" (6). This is good advice, and if we followed it, would go a long way in bringing the light of recognition to the genre. In fact, those interested in exploring critical analysis of YA literature need to be particularly adept scholars because to date there has not been a large body of work created that explores the genre, so there is plenty of opportunity for original scholarship. ${ }^{4}$ Deborah Thacker, in her 
article "Disdain or Ignorance? Literary Theory and the Absence of Children's Literature” concurs. She writes:

The transformation of critical theory over the last few decades has meant that theory needs children's literature. As theorists move from a textual emphasis toward the interplay between reader and text and the social and political forces that mediate those interactions, so the part played by texts written primarily for children and the ways of reading available to children, within a web of discourses that both encourage and control interactions with fictional texts, need to be included and examined. Thus, we, as specialists, must contribute to a broader picture of the social constructedness of readers and the implications of the discourses surrounding fiction in the development of response. (1)

We do, however, need to keep one simple viewpoint in mind: If we want YA literature to be recognized and appreciated as literature, then we should utilize the same theories with it as we use with other literatures, including those pointed out by Jonathan Culler, in his exemplary short work titled Literary Theory: A Very Short Introduction:

Three theoretical modes whose impact, since the 1960s, has been the greatest are the wide-ranging reflection on language, representation, and the categories of critical thought undertaken by deconstruction and psychoanalysis (sometimes in concert, sometimes in opposition); the analyses of the role of gender and sexuality in every aspect of literature and criticism by feminism and then gender studies and Queer theory; and the development of historically oriented cultural criticisms (new historicism, post-colonial theory) studying a wide range of discursive practices, involving many objects (the body, the family, race) not previously thought of as having a history. (121)

For example, the genre of YA literature can be examined as a way to analyze the underlying class ideology of a work, without the text being specifically "about" class conflict. The genre itself, the form itself, could contain ideological messages within the structures of its conventions. ${ }^{5}$ In any case, utilizing theoretical modes such as the ones mentioned would go a long way in legitimizing a genre whose position on the fringe is undeserved.

It is interesting to note that since the burst of power demonstrated by J. K. Rowling in the writing of YA literature, other well-known literary writers have started to explore the form. Joyce Carol Oates' Big Mouth and Ugly Girl and Freaky Green Eyes are two such works. Here we have a major literary figure who finds the form fascinating and worth her talent. Other known literary writers include Gary Soto (Buried
Onions) and Ursula K. Le Guin (The Earthsea Cycle books, in particular).

Best of all, in addition to these major names from the traditional literary "adult" world, though, there are other writers, firmly ensconced in the YA genre, whose work begs to be explored theoretically. One such writer is the well-known Brock Cole. His works include The Goats and The Facts Speak for Themselves, both of which would stand up to an intense genderbased analysis. In The Goats, a boy and a girl, attending summer camp, are stripped of their clothing and abandoned by their campmates on an island. What is supposed to be a harmless prank turns to an exploration of the expectations of males and females when the two of them run away from the island in order to escape their ostracism.

The Facts Speak for Themselves is probably one of the most explicit novels about sexual molestation ever to be designated "young adult." In this powerful work, Cole lets the main character, Linda, tell her own story, and it is one that readers will not soon forget. Linda, in a voice that has become as hollow and emotionless as her inner life, lets the facts speak for themselves, as she reveals her attempt to take over the 'expected' role of an adult woman. There is much to examine here, including the psychological aspects of a young woman facing situations far beyond her comprehension, and a class system that has conveniently allowed her to slip between the cracks.

Another notable author is Louis Sachar and his work Holes. Sachar's plotting strategy within this work is exemplary; there are stories within stories that ultimately fit together like a set of stacking boxes. The story itself can also be explored as a satire that speaks to such issues as juvenile delinquency, moral character, and redemption. Critics could not find a better novel to explore both structurally and thematically. In this same vein is Monster by Walter Dean Myers, a novel that would appeal to structuralists as well as to race theory critics. This novel is written from the point of view of a young black man on trial for murder who decides to tell his story by writing a movie script. This combination of forms (first person narrative and scriptwriting) is highly original and effective, speaking volumes about the influences in this young man's life, as well as revealing the actions of the plot.

Race theory critics would also delight in reading Christopher Paul Curtis's The Watsons Go to Birming- 
ham-1963. Of particular note is his use of humor in a story that explores the heart of racism. And then there is Armageddon Summer, a novel co-written by Jane Yolen and Bruce Coville that explores the religious sentiments of our society as viewed through a female protagonist, Marina, who believes in a God of power and omnipotence, and a male protagonist, Jed, whose skepticism is in stark contrast to Marina's outlook. As the story progresses, in alternate chapters from Jed and Marina's viewpoints-from Yolen's and Coville's viewpoints - the spectrum of belief in the sacred is revealed and challenged in a way that leaves no easy answers.

In fact, the list of writers and works worthy of critical exploration would be much too long to include here, but others of particular note are Robert Cormier ${ }^{6}$ (I Am the Cheese; The Chocolate Wars), Sharon Creech (Walk Two Moons), Jerri Spinelli (Wringer; Stargirl), Laurie Halse Anderson (Catalyst; Speak) and David Almond (Kit's Wilderness; Skellig).

With contemporary artists like these waiting to be explored, theorists should feel genuine excitement about the uncharted territory of YA literature. In this field, there awaits an opportunity to not only expand our knowledge of the young adult genre, but also to expand our knowledge of literature as a whole and to challenge the restrictions of the traditional canon. This is really what literary theorists are striving to accomplish in all of their works, and young adult literature offers another avenue for exploration. In fact, there are great writers and great stories out there simply waiting to be discovered by the literary community. Let's hope we're up to the challenge.

\section{End Notes}

1 An article titled "The Limits of Literary Criticism of Children's and Young Adult Literature" published in The Lion and the Unicorn written by Hans-Heino Ewers, explores the issue of whether or not children's literature should be regarded as art. He references Heinrich Wolgast's essay “The Misery of Our Children's Literature"-a classic article published in 1896 that calls for the valuing of children's literature-in the first half of his own article, analyzing this call in contemporary terms.

2 Frances Fitzgerald's “The Influence of Anxiety” published in Harper's points out the problems inherent in young adult fiction by closely examining the various types, including fantasy, historical, science fiction, and problem novels. The article also examines the historical publication record of young adult texts, pointing out the differences between British and American novels, and it mentions several prominent authors of the young adult genre, and their influence on the American market.

3 Lauren Binnendyk and Kimberly A. Schonert-Reichl's article titled "Harry Potter and Moral Development in PreAdolescent Children," published in the Journal of Moral Education begins by announcing the radical shift children's literature has experienced since the publication of J.K. Rowling's Harry Potter novels stressing the point that these works are much more than simply escapism and fantasy. They argue that the books themselves can be a significant factor in the moral development of children-that the books contribute to children's development and understanding of life.

4 The second part of Hans-Heino Ewer's article addresses the idea that there is an increasing literariness to be found in children's literature. He cautions readers, though, that one has to be careful because of the variables inherent within the genre, including the fact that children have one view of a text, adults another, and that critics must always be aware of which side they are on. Critics must be careful, in other words, that they are critiquing a work using the same criteria they would use for an adult work, rather than as a critique of the suitability of the text for children.

5 For other literary perspectives regarding YA literature, consult the following sources: Yearwood, Stephanie. "Popular Postmodernism for Young Adult Readers: Walk Two Moons, Holes, and Monster.” ALAN Review 29.3 (Spring-Summer 2002): 50-3.; Kidd, Kenneth. "Psychoanalysis and Children's Literature: The Case for Complementarity." The Lion and the Unicorn 28.1 (2004): 109-130.

6 For an excellent discussion regarding Cormier's view of YA literature see: Myers, Mitzi. “ "No Safe Place to Run to": An Interview with Robert Cormier." The Lion and the Unicorn 24.3 (2000): 445-464.

\section{Works Cited}

Anatol, Giselle Liza, ed. Reading Harry Potter: Critical Essays. Westport, Connecticut: Praeger, 2003.

Binnendyk, Lauren, and Kimberly A. Schonert-Reichl. "Harry Potter and Moral Development in Pre-Adolescent Children." Journal of Moral Education 31.2 (2002): 195-201.

Culler, Jonathan. Literary Theory: A Very Short Introduction. Oxford: Oxford UP, 2000.

Davis, Terry. "On the Question of Integrating Young Adult Literature into the Mainstream." ALAN Review 24.3 (1997): 5-8. 
Ewers, Hans-Heino. "The Limits of Literary Criticism of Children's and Young Adult Literature." The Lion and the Unicorn 19.1 (1995): 77-94.

Fitzgerald, Frances. "The Influence of Anxiety." Harper's Sept. 2004: 62-70.

Kidd, Kenneth. "Psychoanalysis and Children's Literature: The Case for Complementarity." The Lion and the Unicorn 28.1 (2004): 109-30.

Myers, Mitzi. "'No Safe Place to Run to': An Interview with Robert Cormier." The Lion and the Unicorn 24.3 (2000): 445-64.

Russell, David L. Literature for Children. 5th ed. Boston: Pearson, 2005.

Schanoes, Veronica L. "Cruel Heroes and Trecherous Texts: Educating the Reader in Moral Complexity and Critical Reading in J. K. Rowling's Harry Potter Books." Reading Harry
Potter: Critical Essays. Ed. Giselle Liza Anatole. Westport, Connecticut: Praeger, 2003. 131-45.

Smith, James Steel. A Critical Approach to Children's Literature. New York: McGraw Hill, 1967.

Stevenson, Deborah. "Sentiment and Significance: The Impossibility of Recovery in the Children's Literature Canon or the Drowning of the Water-Babies." The Lion and the Unicorn 21.1 (1997): 112-30.

Thacker, Deborah. "Disdain or Ignorance? Literary Theory and the Absence of Children's Literature." The Lion and the Unicorn 24.1 (2000): 1-17.

Yearwood, Stephenie. "Popular Postmodernism for Young Adult Readers: Walk Two Moons, Holes and Monster." ALAN Review 29.3 (2002): 50-53. 